APPLIED ISSUE

\title{
Distribution and habitat of unionid mussels and invasive sea lamprey larvae in the Paw Paw River, a tributary of Lake Michigan
}

\author{
BRIDGET L. GRUBER*, SARA A. ALDERSTEIN GONZALEZ ${ }^{\dagger}$, PETER J. BADRA ${ }^{\ddagger}$ AND \\ MATTHEW E. HERBERT ${ }^{\S}$ \\ *Marrone Bio Innovations, CA, U.S.A. \\ †School of Natural Resources and Environment, University of Michigan, Ann Arbor, MI, U.S.A. \\ ${ }^{\ddagger}$ Michigan Natural Features Inventory, Michigan State University, Lansing, MI, U.S.A. \\ ${ }^{\S}$ The Nature Conservancy, Lansing, MI, U.S.A.
}

\section{SUMMARY}

1. Lampricides are commonly used to control invasive sea lampreys (Petromyzon marinus) in tributaries around the Great Lakes (U.S.A.) by targeting their larvae (ammocoetes). As lampricides have sublethal effects on unionids, this study investigated unionid and ammocoete distribution and habitat use to aid in refining lampricide applications.

2. Habitat and unionid surveys were conducted in the Paw Paw River, in south-west Michigan (U.S.A.). Unionids were predominately present in the upper main stem, while the probability of ammocoete presence was highest in the tributaries and lower main stem.

3. Generalised linear models revealed median particle size and gradient to be effective predictors of unionid distributions, while distance to sea lamprey spawning habitat and bank stability were effective predictors of ammocoete distributions.

4. Minimal overlap of unionid and ammocoete distributions suggests that refinement of lampricide treatment in the Paw Paw River is possible. We propose redefining the extent of the treatment unit so that only areas with a high probability of ammocoete presence and a low probability of unionid presence are treated with lampricide. This could result in reducing treatment costs and minimising threats to unionid conservation, while not jeopardising the success of lampricide treatment programmes.

Keywords: distribution, freshwater mussels, habitat, invasion management, sea lamprey

\section{Introduction}

The North American unionid mussels are the most diverse among unionids in the world, with approximately 300 recognised species, 45 of which can be found in Michigan, U.S.A. However, unionid mussels are also one of the most imperilled groups in North America (Williams et al., 1993): 37 species are extinct and about one-third are considered imperilled or critically imperilled (Master et al., 2000). In Michigan, 27 species are listed as endangered, threatened or of special concern (Michigan Admin- istrative Code R299.1021). Decline of mussel populations is attributed directly to pollution and increases in siltation, controls of natural flow regimes (e.g. impoundments), loss of fish hosts and competition and fouling by exotic species (Bogan, 1993). Among these, habitat disturbance is having the most impact (Williams et al., 1993).

Both historical and recent studies on the spatial scale necessary to characterise unionid habitat are contradictory and insufficient (Strayer, 2008). Several studies indicate that local habitat measures, like substratum particle size, in-stream cover (i.e. vegetation, woody debris) and current 
velocity, could sufficiently characterise mussel habitat (van der Schalie, 1938; Huehner, 1987; Strayer \& Ralley, 1993; Hart, 1995; Vaughn, 1997). Yet, other studies showed that these local habitat metrics were not useful in predicting their presence and abundance (Strayer, 1981, 2008; Holland-Bartels, 1990; Vaughn \& Pyron, 1995). Strayer \& Ralley (1993) suggested that large-scale habitat variables may be more effective predictors of unionid mussel distributions in rivers. Large-scale variables such as surficial geology, stream size and land cover were found to influence mussel presence and abundance (Strayer, 1983, 1993; McRae, Allan \& Burch, 2004). McRae et al. (2004) suggested that a combination of these local and large-scale habitat metrics best described unionid distributions.

Unionid mussel populations in the Great Lakes are exposed to an additional potential threat: in-stream chemical applications to control invasive sea lamprey, Petromyzon marinus (Linnaeus, 1758). Sea lamprey are a serious threat to the ecology of the region (Christie \& Goddard, 2003), and the Great Lakes fishery conservatively valued at $\$ 1.5$ billion annually in the late 1990 s (Bence \& Smith, 1999). In the adult phase, they are parasitic on fish in the lakes, causing high mortalities particularly among native lake trout, Salvelinus namaycush (Walbaum, 1792). After spending 12-20 months in the free-swimming parasitic stage, adults migrate up into tributaries where they spawn and die. Sea lamprey larvae (ammocoetes) spend four or more years burrowed into stream sediments feeding on detritus. Once the larval phase is complete, transformers migrate downstream to lakes where they begin their parasitic phase (Applegate, 1950). Sea lamprey control in tributaries harbouring ammocoetes has been primarily through the application of lampricide. TFM (3-trifluoromethyl-4-nitrophenol) is the lethal component of the lampricide (Applegate, Howell \& Moffett, 1961), and occasionally, Baylucide (a molluscicide) is added to reduce the amount of TFM required on larger rivers or to enhance TFM toxicity downstream of an application (Gilderhus, 1979). Tributaries are treated about every three to 10 years depending on how they rank in terms of potential transformer production (Christie et al., 2003; Slade et al., 2003). According to the Great Lakes Fishery Commission, control efforts have resulted in a $90 \%$ reduction in sea lamprey populations in most areas (Dawson, 2007). Lampricide treatments are intended to be selectively toxic to sea lamprey, although some lethal and sublethal effects have been reported on other species (Gilderhus, 1979; Gilderhus \& Johnson, 1980; Bills et al., 1992; U.S. Fish \& Wildlife Service, 1996; Waller et al., 1997; Waller, Rach \& Luoma, 1998; Boogaard, Kolar \& Waller, 2004).
The impact of lampricide on unionid mussels is not well understood; however, studies have reported significant sublethal effects. Unionid mussels may be particularly vulnerable to lampricide with some species being more sensitive than others (Boogaard et al., 2004). Lampricide narcotises mussels leaving them vulnerable to beaching, predation and displacement by currents (Gilderhus, 1979; Gilderhus \& Johnson, 1980; Bills et al., 1992; Waller et al., 1997, 1998). These narcotic effects can last up to 14 days (Waller et al., 1998). M. Hoggarth \& J. Yankie (unpublished data) found that there was an increased likelihood of beaching following TFM treatments in Conneaut Creek, Ohio. Further, when granular Baylucide, which is not selectively toxic, is applied in lentic environments, it remains on the sediment and slowly dissolves in a thin layer of water at the sediment surface where mussels may be living (Gilderhus, 1979). Gilderhus (1979) observed significant reductions in numbers of non-unionid bivalves after granular Baylucide treatments in Boardman Lake in northern Michigan, and found that 13 days after treatment, all bivalves previously enumerated (105) were absent from the study area. The author noted that this was not a surprising result as Baylucide is used as a molluscicide elsewhere.

Modifications to lampricide treatments have been carried out to minimise effects to non-target species (McLaughlin, Marsden \& Hayes, 2003). For example, juvenile lake sturgeon Acipenser fulvescens (Rafinesque, 1817), listed as endangered, threatened or of special concern in Great Lakes states, have low tolerance to TFM (Boogaard, Bills \& Johnson, 2003). As a result, tributaries where both sea lamprey larvae and lake sturgeon exist have been treated by applying lower concentrations of lampricide and later in the season, giving juvenile sturgeon the chance to grow larger and become less susceptible to the chemicals (Johnson, Weisser \& Bills, 1999). Also in response to concerns over the sensitivity of mudpuppies Necturus maculosus (Rafinesque, 1818) to TFM exposure, Ohio tributaries have been treated with lower concentrations of lampricide (Christie, 2000). A similar approach could be envisioned if distributions of sea lamprey larvae and unionids overlap.

In this study, we investigated the distribution and overlap of ammocoetes and unionids in the Paw Paw River, a tributary to Lake Michigan located in south-west Michigan. In Michigan, $60 \%$ of unionid species found in the state are listed as endangered, threatened or of special concern (Michigan Administrative Code R299.1021). Despite this situation, no studies to date have investigated the overlap in unionid distributions with sea lamprey larvae to explore the need and options for modifications to 
lampricide control. In general, distributions may overlap as both sea lamprey larvae and unionid mussels are benthic organisms that require substratum stability and a regular supply of food. Nevertheless, ammocoetes feed on detritus and are most often found in depositional areas of slow current and soft sediments of sand and fine organic matter (Slade et al., 2003), while unionids filter feed and as a group have a wide range of habitat preferences. Most unionid species are associated with substrata of sand and gravel, or sand, gravel and pebble mixes and with moderate currents (Huehner, 1987; Hart, 1995; Badra \& Goforth, 2003; McRae et al., 2004). A small number of species, such as Pyganodon grandis (Say, 1829), are often found in depositional areas - habitat similar to that of ammocoetes (Huehner, 1987; Hart, 1995). We hypothesised that ammocoetes and unionid mussel species in the Paw Paw River have separate distributions and are associated with habitat of different characteristics, allowing for the refinement of lampricide applications. Specific objectives of our study were to investigate the habitat characteristics associated with the presence of unionid mussels and ammocoetes in the Paw Paw River and to compare the overlap in their distributions.

\section{Methods}

\section{Study sites}

We selected the Paw Paw River for this study as historical surveys conducted within the system indicated the presence of both sea lamprey ammocoetes and unionids. Since available data on unionids were very limited, we conducted surveys for distribution and local habitat. For analysis of ammocoete distributions, we used historical surveys, conducted by the U. S. Fish \& Wildlife Service (USFWS) to rank the system for lampricide treatment. We did not collect additional larval data during our survey as the system was treated with lampricide shortly before our sampling. We investigated the relationships between distribution and habitat using a regression approach, where the presence of selected species of unionids (most common) and of ammocoetes was modelled as a function of local-scale and landscape-scale habitat variables relevant to each group. We obtained landscape-scale habitat data from available databases and derived additional habitat data from maps. We also compared the distribution of the most common species of unionids to ammocoete distribution.

The Paw Paw River is the northern-most tributary of the St. Joseph River located in south-west Michigan, one of the largest catchments in Michigan's Lower Peninsula draining $12.134 \mathrm{~km}^{2}$ into Lake Michigan. The Paw Paw catchment covers approximately $715 \mathrm{~km}^{2}$. The main stem and lower reaches of the Paw Paw River have cool water temperatures with modelled July weekly means between 19 and $22{ }^{\circ} \mathrm{C}$, and are run-off driven (Seelbach et al., 1997). The upper reaches and tributaries have cold water temperatures with modelled July weekly means between 14 and $19{ }^{\circ} \mathrm{C}$ and are groundwater driven (Seelbach et al., 1997). Much of the catchment channels are composed of sand, and the majority of the land cover consists of farmland, orchards and vineyards. Headwaters have base flows up to $0.5 \mathrm{~m}^{3} \mathrm{~s}^{-1}$, while in the main stem they range between 5.7 and $12.7 \mathrm{~m}^{3} \mathrm{~s}^{-1}$ [Michigan Department of Information Technology, Center for Geographic Information (http://www.mcgi.state.mi.us/mgdl)].

\section{Local habitat and mussel data}

We surveyed 45 sites in the Paw Paw River in wadable areas between June and October 2009. Location of the sites, although influenced by accessibility, was chosen to obtain a spatial representation of the entire Paw Paw system and the catchment's surficial geology. We also considered the location of historical ammocoete surveys. Sites on tributaries were accessed from road crossings, while most sites on the main stem were accessed by canoeing. At each survey site, we measured substratum particle size, assessed habitat and counted live unionid mussels.

Substratum particle size was measured at the first 25 sites both by performing pebble counts and by visual estimation, and these data were compared to determine whether visual estimation was reliable to assess the particle size in the rest of sites (Wolman, 1954). Samples for pebble counts were collected by walking upstream from bank to bank. The first particle touched at each step was measured using a gravelometer. When 100 particles were measured, the counter completed the crossing to the other side of the channel (Wolman, 1954; Kondolf, 1997). Visual inspection was based on estimating the per cent coverage of boulder (diameter $>256 \mathrm{~mm}$ ), cobble (256$64 \mathrm{~mm})$, pebble $(64-16 \mathrm{~mm})$, gravel $(16-2 \mathrm{~mm})$, sand (2$0.0625 \mathrm{~mm})$ and silt $(<0.0625 \mathrm{~mm})$. Estimates based on pebble counts and visual inspection in the 25 sites were similar (chi-square test, $P=0.282$ ). Substratum data were also used to assess the sea lamprey spawning habitat: if a site consisted of $10 \%$ or more of gravel or larger substratum, it was considered suitable sea lamprey spawning habitat.

Habitat assessment was based on scores of six metrics: substratum quality, in-stream cover, channel morphology, 
riparian zone and bank stability, pool and riffle quality and gradient [Ohio EPA Qualitative Habitat Evaluation Index (QHEI), see Rankin, 2006; \& Ohio EPA, 2006]. All metrics received individual scores that were totalled for a maximum of 100 points at each site. The first five metrics were visually scored at the site, a $128-\mathrm{m}^{2}$ area, and the gradient score was calculated as the ratio of gradient $\left(\mathrm{m} \mathrm{km}^{-1}\right)$ to drainage area $\left(\mathrm{km}^{2}\right)$ obtained from maps.

Unionid mussels were identified to species and enumerated within an area of $128 \mathrm{~m}^{2}$ at each survey site. If a wadable area of this size was not found at the site, the largest possible wadable area was surveyed. The area searched at each site $\left(128 \mathrm{~m}^{2}\right)$ was chosen (i) to maximise search effort at each site while allowing an appropriate number of sites to be completed within the financial and temporal scope of the project and (ii) to stay consistent with a substantial number of recent unionid surveys in Michigan that have used this as a standard search area (Badra, 2010). The entire selected area was searched for live unionid mussels tactilely and visually with the use of glass bottom buckets. This is a well-established method of increasing visual detection of mussels and a widely used technique for mussel surveys (Badra \& Goforth, 2003; Strayer \& Smith, 2003; McRae et al., 2004).

Preliminary analysis to select variable predictors for the regression analysis indicated that median particle size was significantly correlated with the scores of substratum quality $(r=0.84)$, channel morphology $(r=0.67)$ and riparian zone $(r=0.68)$. Further, in-stream cover score was significantly correlated with bank stability score $(r=0.71)$. Finally, the pool and riffle quality score did not vary among sites. Therefore, from the local habitat assessment, only the bank stability score was retained for the analysis. This score was based on bank erosion, and sites were classified as having (i) moderately stable banks or (ii) stable banks.

\section{Landscape habitat data}

We obtained landscape habitat data from the Michigan Department of Natural Resources Landscape-Based Ecological Classification System for River Valley Segment Classification (MI-VSEC) database (Seelbach et al., 1997). The database contained landscape habitat data at the resolution of valley segments, defined as 'structurally homogeneous' and 'ecologically distinct' spatial units along a stream (Seelbach et al., 1997). Landscape habitat variables were linked to the survey sites using georeferenced locations and ArcMap v. 9.3.1 (ESRI, 2009).

Preliminary analysis to select landscape habitat predictors for the regression model among the MI-VSEC data showed that variables that are potentially influential on distributions such as valley origin and modelled temperature were strongly correlated with hydrology. We selected hydrology and gradient $\left(\mathrm{m} \mathrm{km}^{-1}\right)$ as variables for the regression. Hydrology classifies valley segments in numerous categories based on the intensity of base and peak flows (Seelbach et al., 1997). We aggregated the hydrology categories present in the Paw Paw River into groundwater or run-off driven. Finally, gradient was significantly correlated with gradient/drainage area score $(r=0.67)$ described in the previous section.

\section{Sea lamprey larvae and habitat data}

Data on larval sea lamprey densities and habitat were from historical records of Quantitative Assessment Surveys (QAS) and distribution surveys conducted in the Paw Paw River by the USFWS (Slade et al., 2003). These surveys are organised by non-overlapping 'stream reaches' (Anonymous, 2001) and were surveyed for the type and amount of habitat and ammocoete densities. Habitat data recorded were length of substratum types: I, II, III and spawning habitat measured along four transects at each site (Slade et al., 2003). Type I is the preferred ammocoete habitat, generally located in depositional areas and composed of mostly sand and fine organic matter. Type II is composed of mostly sand and may include some gravel. Both types I and II are suitable for larvae but type I is the preferred habitat and densities are higher than in type II habitat (Slade et al., 2003). Type III is not suitable for ammocoetes as they cannot burrow into it, as it is composed of hardpan clay, densely packed gravel or bedrock (Slade et al., 2003). Spawning habitat consists of substratum larger than $9 \mathrm{~mm}$ in diameter with some sand and flow velocities between 0.5 and $1.5 \mathrm{~m} \mathrm{~s}^{-1}$ (Anonymous, 2001). The Paw Paw River consists of five reaches; Reach 4 is the main stem, and Reaches 5, 6, 7 and 8 are the larger tributaries (Figs $1 \& 2$ ). Data were collected during spring and summer 1999, 2000 and 2004 at 52 access sites. At each site, ammocoetes were sampled in two $15-\mathrm{m}^{2}$ plots placed in habitat type I using an electrofisher. Ammocoetes were also surveyed in type II habitat but only in two plots, and these data were excluded from the analysis. Ammocoetes were collected, identified to the species level (several species of native lamprey are found in Michigan streams), counted and measured (Slade et al., 2003).

For the analysis, we aggregated ammocoete counts into length categories taken to represent age: $50-100 \mathrm{~mm}=$ age 1 and $>100 \mathrm{~mm}=$ age 2 and older including transformers. We did not include young-of-the-year data $(<50 \mathrm{~mm})$ in the 


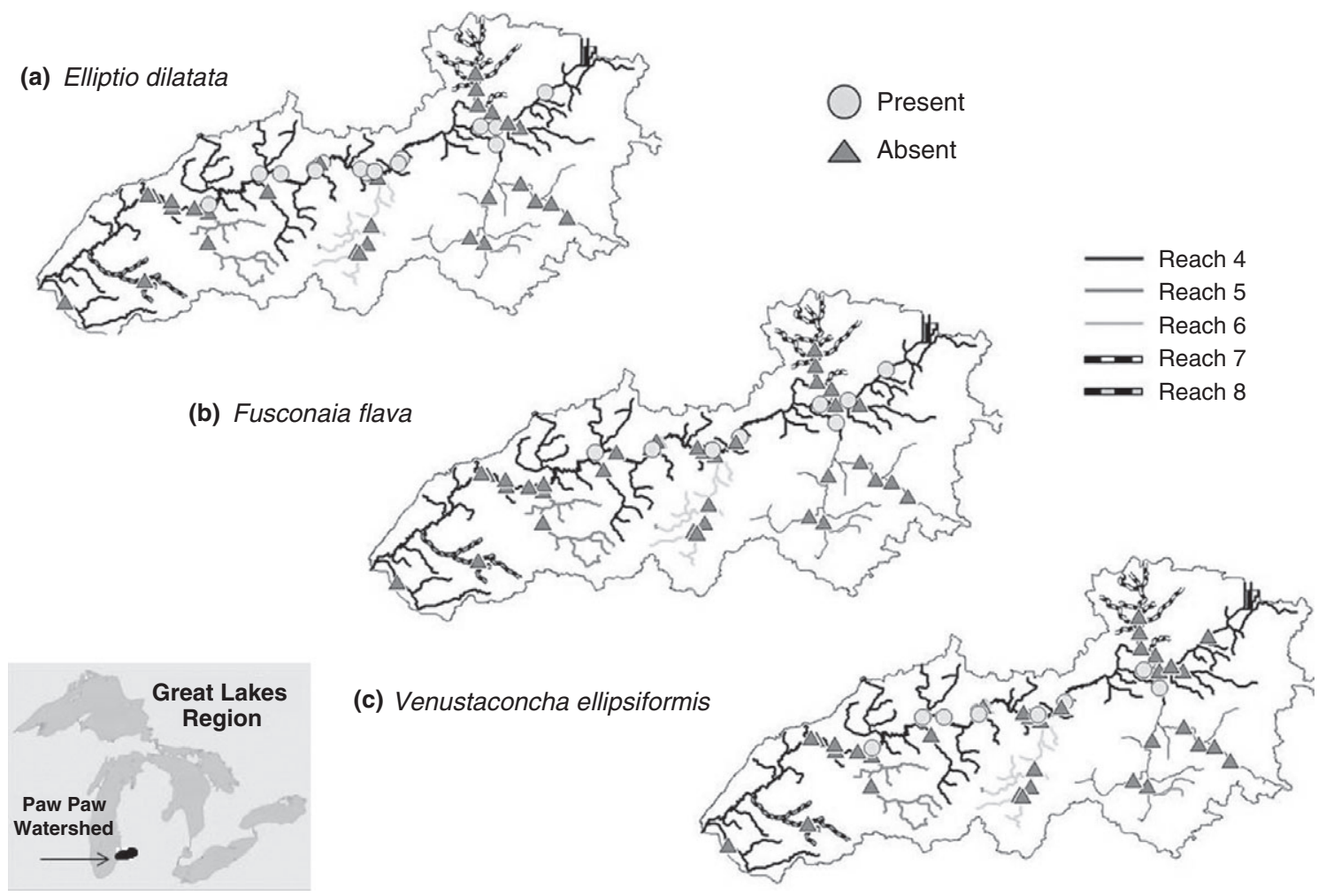

Fig. 1 Sampling sites from the survey conducted in the Paw Paw River for this study indicating the presence of (a) Elliptio dilatata, (b) Fusconaia flava and (c) Venustaconcha ellipsiformis. Reaches are units defined by the Great Lakes Fisheries Commission for sea lamprey larvae assessment and control. The Paw Paw River Catchment's location in the Great Lakes Region is noted.

analysis as larvae are too small to be well assessed with an electrofisher (Slade et al., 2003). To spatially link the sample location of ammocoetes and unionids, if ammocoete sampling plots fell within $10 \mathrm{~m}$ of unionid survey sampling plots, they were considered the same site.

We introduced the distance to spawning habitat from sites upstream of sampling locations as a covariate in the analysis. The distribution of ammocoetes is determined not only by the characteristics of the habitat suitable for the larvae but also by the spawning locations from which larvae drift downstream (Adlerstein \& Silverman, 2008). Distance to spawning habitat was calculated by determining the distance between each larval sampling plot to the nearest upstream location where spawning habitat was recorded during QAS, other historical surveys and the survey conducted during this study. For the calculations, we used ArcMap v. 9.3.1 (ESRI, 2009).

Other considerations for the analysis of lamprey distributions

For the analysis of sea lamprey larvae, we considered the schedule of the lampricide treatment. We selected larval data from surveys conducted more than 2 years after a treatment because it takes approximately 2 years after larvae are eradicated by treatment to find ammocoetes in streams (Adlerstein \& Silverman, 2008). Treatments, similar to surveys, are organised by reaches individually ranked for lampricide treatment, so that not all reaches are treated within the same year. Schedules provided by the USFWS indicate that lampricide was applied during 1988, 1997 and 2001, corresponding to two to 12 years before QAS were conducted. If ammocoetes were present at a site in any sampling year, that site was considered a presence site for all samples.

\section{Statistical analysis}

The relationships between ammocoete and unionid distributions and habitat in the Paw Paw River were investigated using regression techniques. We modelled the presence of unionid species, ammocoetes age 1 and ammocoetes age $2+$ as a function of selected habitat variables. For the analysis, we used generalised linear models (GLM) (McCullagh \& Nelder, 1989). In all cases, a binomial probability distribution was used to represent the presence/absence response variable. 


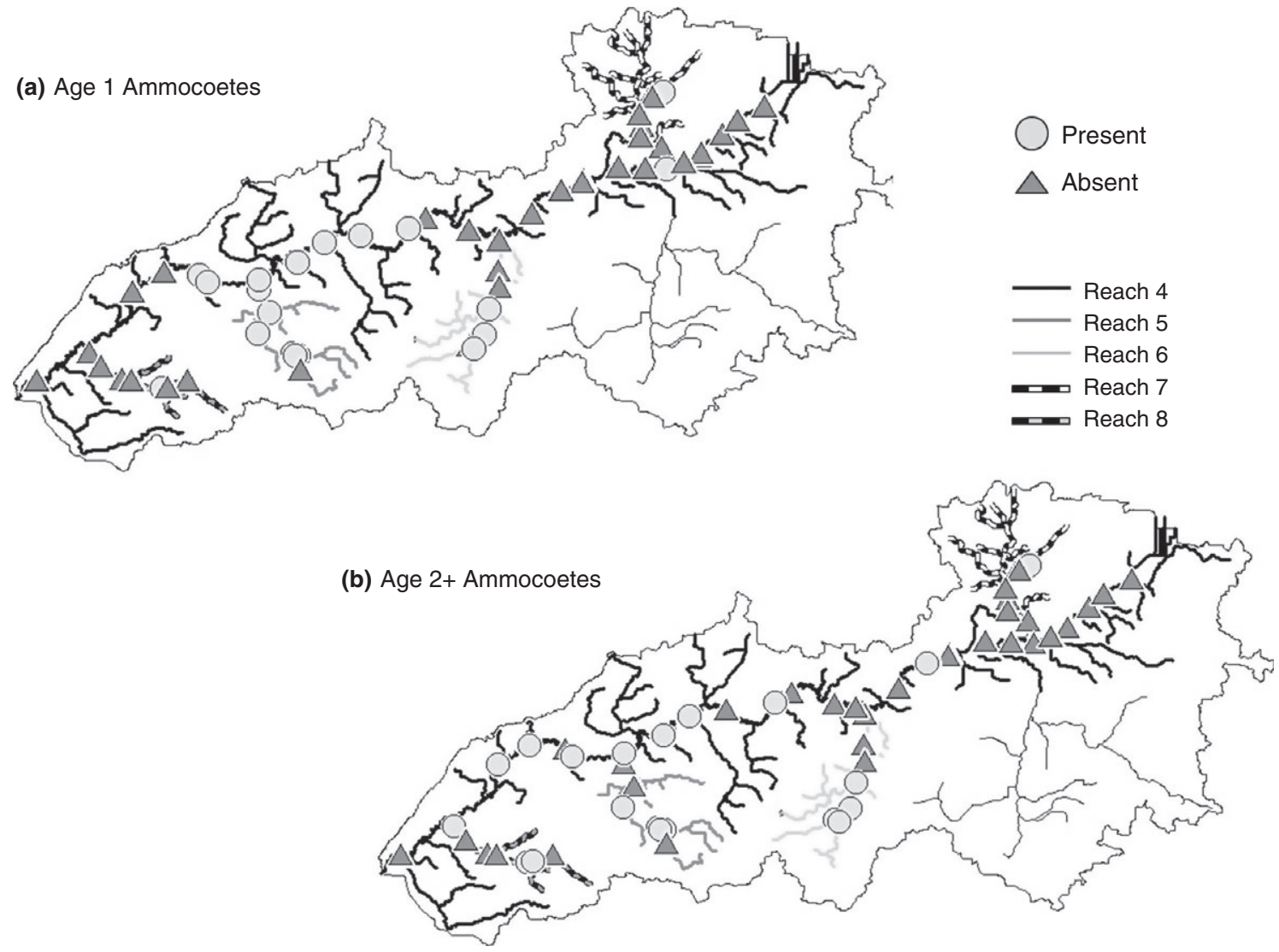

Fig. 2 Sampling sites from the Quantitative Assessment Surveys conducted in the Paw Paw River in 1999, 2000 and 2004 by the US Fish \& Wildlife Service indicating the presence of (a) age 1 and (b) age 2+ sea lamprey larvae. Reaches are units defined by the Great Lakes Fisheries Commission for sea lamprey larvae assessment and control.

The distribution of each unionid species was modelled using the following GLM:

$$
g\left(\mu_{b m d}\right)=\alpha+\xi_{b}+\beta X_{m}+\delta X_{d}
$$

where $\mu$ was the expected probability of the unionid species to be present modelled as a function of bank stability $b$, median particle size $m$ and gradient $d$, and $\mathrm{g}()$ was the logit link function $\ln \left[\mu_{m d b} /\left(1-\mu_{m d b}\right)\right]$ relating the response and the linear predictor. Median particle size and gradient were introduced as covariates, and bank stability was introduced as a factor with two levels. Hydrology $h$ was initially in the model but found to be correlated with median particle size and was not retained as a predictor.

The distributions of age 1 and age $2+$ ammocoetes were modelled using the following GLM:

$$
g\left(\mu_{h b s}\right)=\alpha+\delta_{h}+\xi_{b}+\beta \lambda_{s}
$$

where $\mu$ was the expected probability of ammocoetes to be present modelled as a function of hydrology $h$, bank stability $b$ and distance to spawning habitat $s$, and $g()$ was the logit link function. Hydrology and bank stability were introduced as factors, and distance to spawning habitat was introduced as a covariate. Median particle size $m$ and gradient $d$ were initially in the model but were found to be highly correlated with distance to spawning habitat and hydrology, respectively, and were not retained as model predictors.

We conducted analysis of deviance to test the significance of the effect of each predictor by comparing full models and models excluding the tested variable. We examined residuals to assess fits and departures of covariate linearity. Tests were performed at the 95\% confidence levels. Routines available in the S-PLUS computing environment to run glm () were used to conduct the analysis (TIBCO Software Inc, 2007).

\section{Results}

\section{Mussel and ammocoete distributions}

Live mussels were found at 17 of the 45 sites in the Paw Paw River. All sites with live individuals were 
Table 1 Summary of Paw Paw River habitat data by reach. Reaches are units defined by the Great Lakes Fisheries Commission for sea lamprey larvae assessment and control

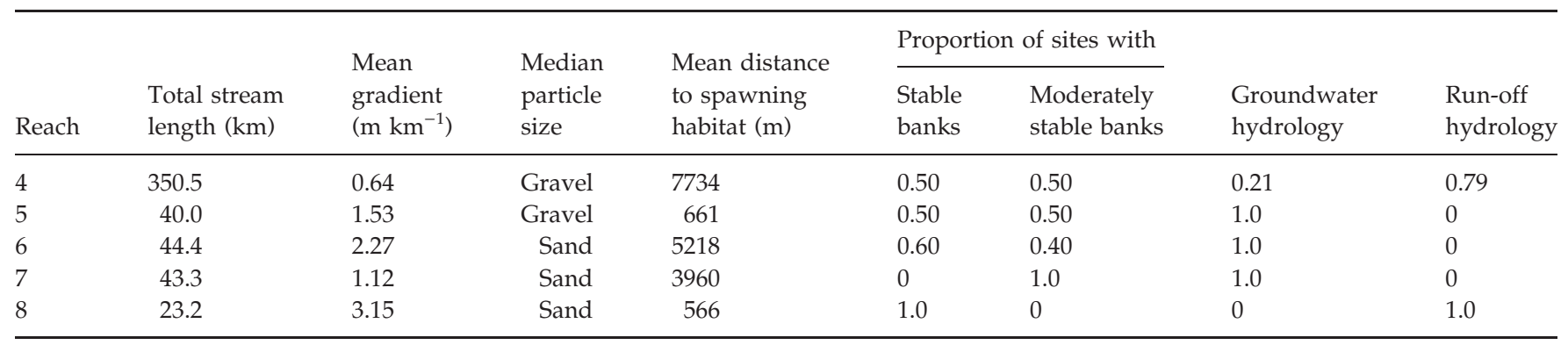

Gradient and hydrology data are from the Michigan Department of Natural Resources Landscape-Based Ecological Classification System for River ValleySegmentClassification (MI-VSEC) database (Seelbach et al., 1997), medium particle sizeand bank stability data are from surveys conducted for this study, and distance to spawning habitat is from surveys conducted by the US Fish \& Wildlife Service and surveys conducted for this study.

located on Reach 4 (Fig. 1). A total of 842 live unionid mussels were counted representing nine species. The mean density of all species combined at sites where live individuals were present was 0.59 individuals $\mathrm{m}^{-2}$, and reached a maximum of 5.09 individuals $\mathrm{m}^{-2}$. The number of live species per site ranged from zero to seven with a mean of three at sites where live unionids were present. The three most common species were Elliptio dilatata (Rafinesque, 1820), Fusconaia flava (Rafinesque, 1820) and Venustaconcha ellipsiformis (Conrad, 1836), present at 36,20 and $22 \%$, respectively, of the total sites. Other species found live were Amblema plicata (Say, 1817), Strophitus undulatus, Lampsilis siliquoidea (Barnes, 1823), Lasmigona costata (Rafinesque, 1820), Pleurobema sintoxia (Rafinesque, 1820) and Villosa iris (I. Lea, 1829). These species were present at $4 \%$ or less of the total sites.

Sea lamprey larvae were present throughout the main stem and tributaries of the Paw Paw River except in the South and East branches (Fig. 2) because of a dam that is impassable by adult sea lamprey. The mean density of ammocoetes at sites where individuals were present was 0.43 ammocoetes $\mathrm{m}^{-2}$, and reached a maximum of 2.4 ammocoetes $\mathrm{m}^{-2}$ with higher densities in the tributaries. Age 1 and age 2+ larvae were present at 39 and $42 \%$, respectively, of the total sites.

\section{Habitat variables}

Median particle size in the Paw Paw River ranged from 0.06 to $9 \mathrm{~mm}$, and $48 \%$ of the sites had moderately stable banks, while $52 \%$ had stable banks measured by the local habitat assessment. Based on valley segment classification, gradient in the study sites along the Paw Paw River ranged from 0.04 to $4.36 \mathrm{~m} \mathrm{~km}^{-1}$ and $36 \%$ of sites were run-off driven, while $64 \%$ were groundwater driven.
Calculated distance to sea lamprey spawning habitat from sites assessed for larvae during QAS surveys to plots upstream ranged from 0 to $25.851 \mathrm{~m}$. For a summary of the habitat data, see Table 1.

\section{Relationships between distributions and habitat}

The distributions of E. dilatata, F. flava and V. ellipsiformis were significantly related to one or both of the following habitat variables included in the analysis: gradient and median particle size (Table 2). All three species had a significant negative relationship with gradient (Fig. 3). Elliptio dilatata had the strongest negative relationship with gradient, and F. flava the weakest. This variable accounted for most of the explained deviance in all of the models (Table 2). V. ellipsiformis displayed a significant positive relationship with median particle size (Fig. 3).

The distributions of age 1 and age 2+ ammocoetes were significantly dependent upon distance to spawning habitat and bank stability (Table 3). For both age groups, the probability of finding organisms was higher in areas with more stable banks, and for age 2+ ammocoetes, the difference was significant at the $95 \%$ confidence level (Figs 4 \& 5). The probability of finding ammocoetes decreased as the distance to spawning habitat grew larger, and for age 1, the decline was significant at the 95\% confidence level (Figs $4 \& 5$ ).

The distribution of both ammocoete age groups overlapped minimally with the distribution of the three most common unionid species in the Paw Paw River. Unionids were only present in Reach 4, and although ammocoetes age 1 and age 2+ were found in all reaches (Table 4), the probability of larval presence was lowest in that reach, as well as in Reach 7. Also, densities of ammocoete were lowest in Reach 4. 
Table 2 Analysis of deviance for binomial generalised linear models for the presence of Elliptio dilatata, Fusconaia flava and Venustaconcha ellipsiformis in the Paw Paw River as a function of median particle size, gradient and bank stability

\begin{tabular}{|c|c|c|c|c|c|c|}
\hline $\begin{array}{l}\text { Deviance } \\
\text { Null Model }\end{array}$ & \multicolumn{2}{|l|}{57.68} & \multicolumn{2}{|l|}{44.58} & \multicolumn{2}{|l|}{47.16} \\
\hline $\begin{array}{l}\text { Median particle } \\
\text { size }\end{array}$ & 2.68 & 4.7 & 1.96 & 4.4 & 8.12 & $17^{*}$ \\
\hline Bank stability & 0.22 & 0.38 & 0.19 & 0.43 & 0.024 & 0.05 \\
\hline Full Model & 20.9 & 36 & 9.10 & 20 & 23.5 & 50 \\
\hline
\end{tabular}

Median particle size and gradient were introduced as covariates. Bank stability was a factor with two levels (moderately stable, stable). * indicates that the variable is significant (probability of chi $<0.05$ ).
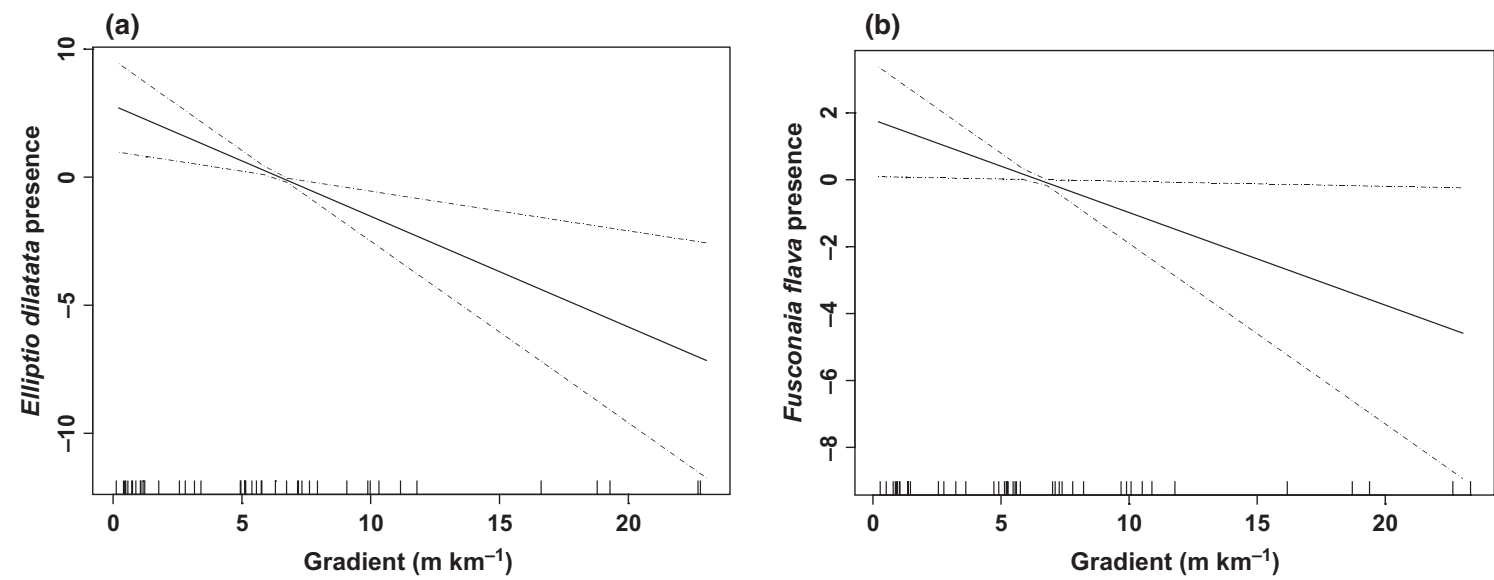

(c)

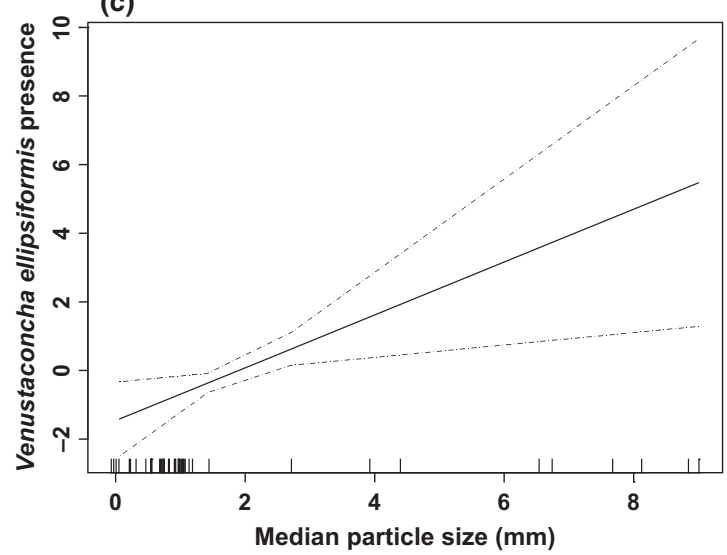

(d)

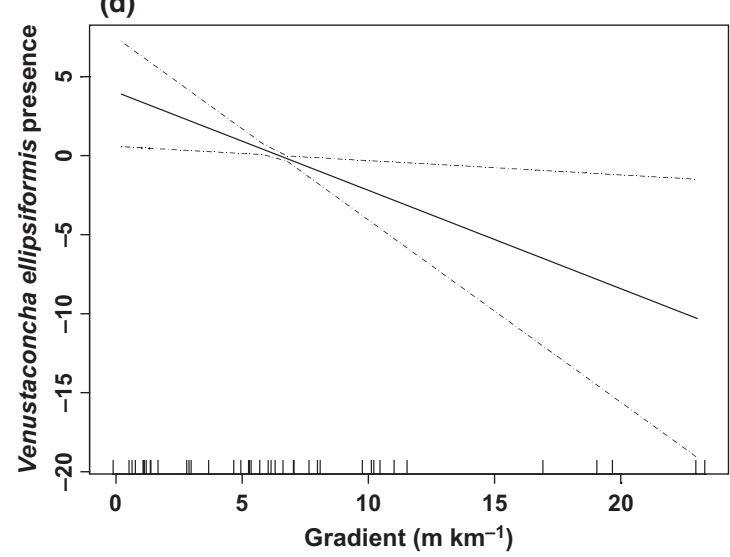

Fig. 3 Fitted probability of (a) Elliptio dilatata presence as a function of gradient, (b) Fusconaia flava presence as a function of gradient, (c) Venustaconcha ellipsiformis presence as a function of median particle size and (d) Venustaconcha ellipsiformis presence as a function of gradient from binomial generalised linear models. Models included gradient, median particle size and bank stability; only significant relationships are represented in this figure. The $Y$ axis is standardised, so zero represents mean probability of finding an individual. Bars on $X$ axis represent the predictor value for each data point. Dashed line represents the $95 \%$ confidence envelopes.

\section{Discussion}

There was a minimal overlap in distributions of the most common unionid mussels - E. dilatata, F. flava and
V. ellipsiformis - and age 1 and age 2+ larval sea lamprey in the Paw Paw River. In Reach 4 (the main stem), where unionids were predominately present, ammocoetes were absent or present in low densities. This is particularly the 
Table 3 Analysis of deviance for binomial generalised linear models for the presence of ammocoetes age 1 and age 2+ in the Paw Paw River as a function of distance to spawning habitat, hydrology and bank stability

\begin{tabular}{|c|c|c|c|c|}
\hline \multirow{3}{*}{$\begin{array}{l}\text { Deviance } \\
\text { Null } \\
\text { Model }\end{array}$} & \multicolumn{2}{|c|}{$\begin{array}{l}\text { Age } 1 \text { larvae } \\
(50-100 \mathrm{~mm})\end{array}$} & \multicolumn{2}{|c|}{ Age $2+$ larvae $(>100 \mathrm{~mm})$} \\
\hline & \multicolumn{2}{|l|}{68.21} & \multicolumn{2}{|l|}{79.23} \\
\hline & $\begin{array}{l}\text { Deviance } \\
\text { explained }\end{array}$ & $\begin{array}{l}\text { Percentage } \\
\text { explained }(\%)\end{array}$ & $\begin{array}{l}\text { Deviance } \\
\text { explained }\end{array}$ & $\begin{array}{l}\text { Percentage } \\
\text { explained }(\%)\end{array}$ \\
\hline $\begin{array}{l}\text { Distance to } \\
\text { spawning } \\
\text { habitat }\end{array}$ & 5.66 & $8.3^{*}$ & 2.91 & $3.7^{* *}$ \\
\hline Hydrology & 0.07 & 0.10 & 0.18 & 0.23 \\
\hline Bank stability & 3.21 & $4.7^{* *}$ & 5.70 & $7.2^{*}$ \\
\hline Full Model & 8.95 & 13 & 8.81 & 11 \\
\hline
\end{tabular}

Distance to spawning was introduced as a linear covariate and hydrology (ground water, run-off) and bank stability (moderately stable, stable) were introduced as factors. ${ }^{*}$ indicates probability of chi $<0.05, * *<0.10$.

(a)

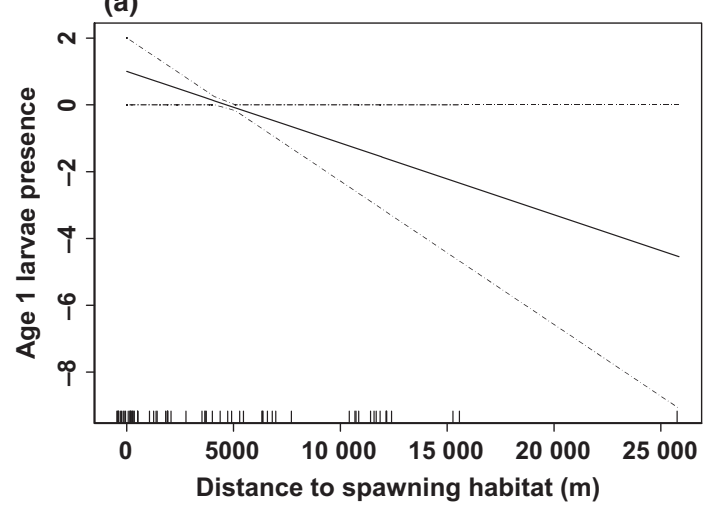

(b) Moderately stable

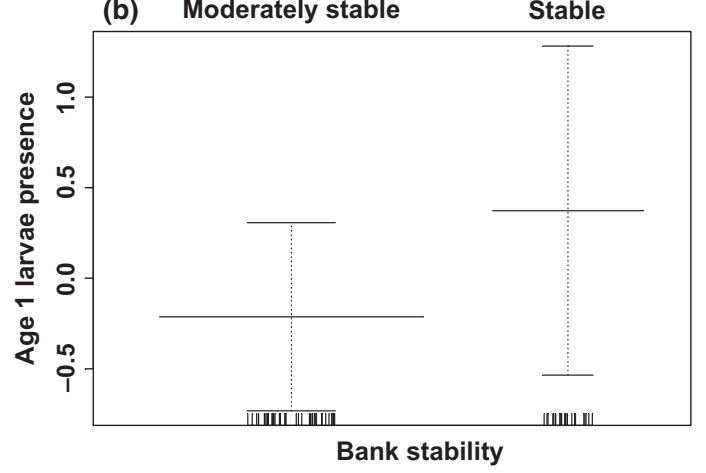

Fig. 4 Fitted probability of age 1 sea lamprey larvae (50-100 mm) presence in the Paw Paw River as a function of (a) distance to spawning habitat and (b) bank stability from a binomial generalised linear model. The model also included hydrology found to be not significant. Refer to Fig. 3 for other figure descriptions.

case in the upper portion of the reach. The probability of finding ammocoetes was highest in the tributaries where unionid mussels were absent. These distributions indi- (a)

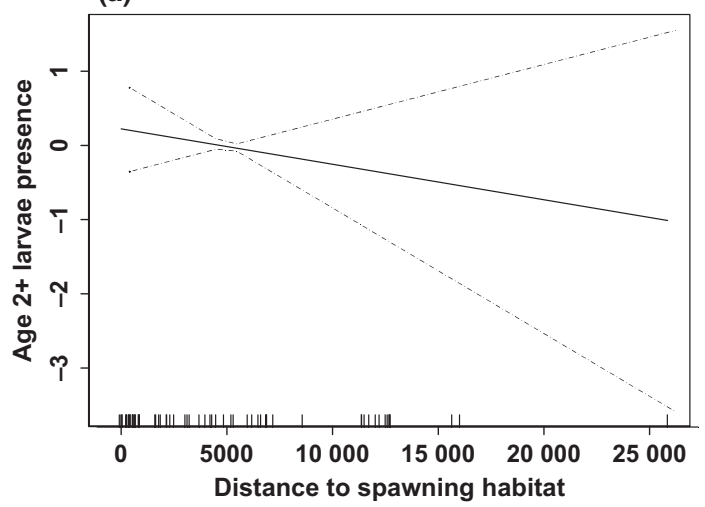

(b)

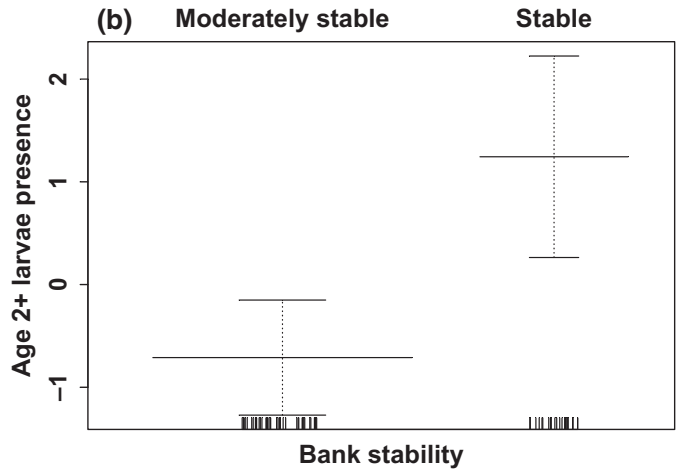

Fig. 5 Fitted probability of age 2+ sea lamprey larvae (>100 mm) presence in the Paw Paw River as a function of (a) distance to spawning habitat and (b) bank stability from a binomial generalised linear model. The model also included hydrology found to be not significant. Refer to Fig. 3 for other figure descriptions.

Table 4 Proportion of sites with unionid species and ammocoete age groups present by reach defined for sea lamprey management in the Paw Paw River

\begin{tabular}{llllll}
\hline Reach & $\begin{array}{l}\text { Elliptio } \\
\text { dilatata }\end{array}$ & $\begin{array}{l}\text { Fusconaia } \\
\text { flava }\end{array}$ & $\begin{array}{l}\text { Venustaconcha } \\
\text { ellipsiformis }\end{array}$ & $\begin{array}{l}\text { Age 1 } \\
\text { ammocoetes }\end{array}$ & $\begin{array}{l}\text { Age 2+ } \\
\text { ammocoetes }\end{array}$ \\
\hline 4 & 0.63 & 0.33 & 0.38 & 0.11 & 0.20 \\
5 & 0 & 0 & 0 & 0.45 & 0.39 \\
6 & 0 & 0 & 0 & 0.14 & 0.29 \\
7 & 0 & 0 & 0 & 0.22 & 0.11 \\
8 & 0 & 0 & 0 & 0.15 & 0.23 \\
\hline
\end{tabular}

Unionid data are from surveys conducted for this study, and ammocoete data were recorded during Quantitative Assessment Surveys conducted by the US Fish \& Wildlife Service in 1999, 2000 and 2004.

cated that Reach 4 was relatively unimportant as an ammocoete producer and was particularly important to unionids.

The minimal overlap in the distribution of unionids and sea lamprey larvae can be explained by differences in habitat. Reach 4 was not ideal for lamprey larvae in sections where habitat was not stable and runoff 
conditions prevailed; these characteristics were found in the upper section of the reach. Higher probabilities of finding larvae in tributaries were significantly related to proximity to spawning habitat and to stable bank conditions, such that probabilities ranged from 0.11 in the main stem to 0.45 in the most stable tributary. Bank stability, which was measured locally, is indicative of flow stability. Run-off conditions cause flows to be unstable and scour out the fine organic matter (Seelbach et al., 1997), which is a component of preferred substratum of ammocoetes (Slade et al., 2003). Flashier flows can also push ammocoetes downstream, as they grow older, away from spawning sites to more stable habitat of slower currents and finer substratum. Indeed, age $2+$ ammocoetes were found in highest densities in the lower portion of the main stem, further away from spawning habitat than age 1 ammocoetes. It is likely that as ammocoetes grow older, flashy flows push them downstream, causing older lamprey to be found at sites at increasing distances from spawning habitat. These observations are consistent with findings by Adlerstein \& Silverman (2008) from a similar analysis covering several systems in Michigan's Lower Peninsula including slightly different predictors. Although not ideal for sea lamprey larvae, Reach 4 contained suitable habitat for unionid mussels, in particular in the upper section. Although the three most common species in the Paw Paw River were found in locations with dissimilar characteristics, these characteristics were mostly outside of those of ammocoete habitat. For example, model results indicated that the presence of the three unionids was positively associated with stable bank conditions but none of the relationships was significant, while the relationship for ammocoetes age $2+$ was significant. Thus, the stability of upper Reach 4 fell within the range suitable for unionid mussels, however, not for ammocoetes. Mussels have more mass than larval sea lamprey and therefore may be more tolerant of slightly less stable flows that can cause scouring of larvae, and larvae age $2+$ are more likely to swim and be exposed to the currents.

Our results on unionid distribution related to substratum particle size are consistent with findings in previous studies and also explain the little overlap found with sea lamprey larvae. The presence of all three of the most common species was positively associated with increases in median particle size in the models, and the relationship was significant for $V$. ellipsiformis. These results are similar to those reported by Hart (1995) and McRae et al. (2004), indicating that F. flava preferred sand and gravel mixes, and by Huehner (1987), reporting that $V$. ellipsiformis and $E$. dilatata preferred sand, gravel and pebble mixes. The habitat in the upper sections of Reach 4 consisted of coarse substratum, suitable for unionid mussels. This substratum composition is similar to the sea lamprey type II habitat, which is less suitable for larvae.

Our results indicating unionid preference for low gradient are consistent with findings in previous studies. The presence of the three most common mussel species was significantly predicted by decreases in gradient. This is consistent with results by Strayer (1993) who found gradient to significantly predict the presence of some unionid species in the northern Atlantic Slope; though, gradient in Lower Michigan streams is generally lower than gradient in streams of the northern Atlantic Slope. Gradient in the Paw Paw River ranged from 0.04$4.36 \mathrm{~m} \mathrm{~km}^{-1}$, and that in the upper section of Reach 4, where unionids were predominately found, was $<1.4 \mathrm{~m} \mathrm{~km}^{-1}$. Gradient probably also affects the distribution of sea lamprey larvae, but the relationship could not be assessed as gradient in the Paw Paw River is correlated with the distance to sea lamprey spawning habitat, so that high gradient increases this distance.

Larval lamprey data were not obtained at the same time as data on mussels because the Paw Paw River was treated with lampricide earlier that year (2009). Thus, there were no larvae in the system when the mussel survey was conducted. It is very likely that ammocoete distributions have remained similar to those observed during QAS conducted between 1999 and 2004 in the Paw Paw River reaches because interannual variation among sampled locations was low. In particular, presence/absence of ammocoetes in sampling locations was consistent. Further, analysis of densities within tributaries regularly assessed by QAS to rank reaches for lampricide treatments has historically shown that sea lamprey assessment data exhibit similar patterns across years (Klar \& Schleen, 1999; Schleen \& Klar, 2002; Young \& Klar, 2003).

Results from our analysis can be influenced by differences in the sample design of unionid mussel surveys compared to sea lamprey surveys. Unionid surveys were conducted within $128 \mathrm{~m}^{2}$ plots (Badra, 2010), while ammocoetes were sampled within $15 \mathrm{~m}^{2}$ plots (Slade et al., 2003). Additionally, during QAS, ammocoetes are not sampled at random but collected in type I habitat where ammocoete presence is most likely (Slade et al., 2003). This explains the small variation in ammocoete presence among sites in the Paw Paw River (low null deviance in the generalised linear models). Non-random sampling reduces the opportunities to find contrast in habitat variables to predict ammocoete distribution but would not invalidate the relationships found.

Our results present opportunities for sea lamprey control refinement and warrant additional studies in other Great Lakes tributaries. Although sea lamprey larvae and 


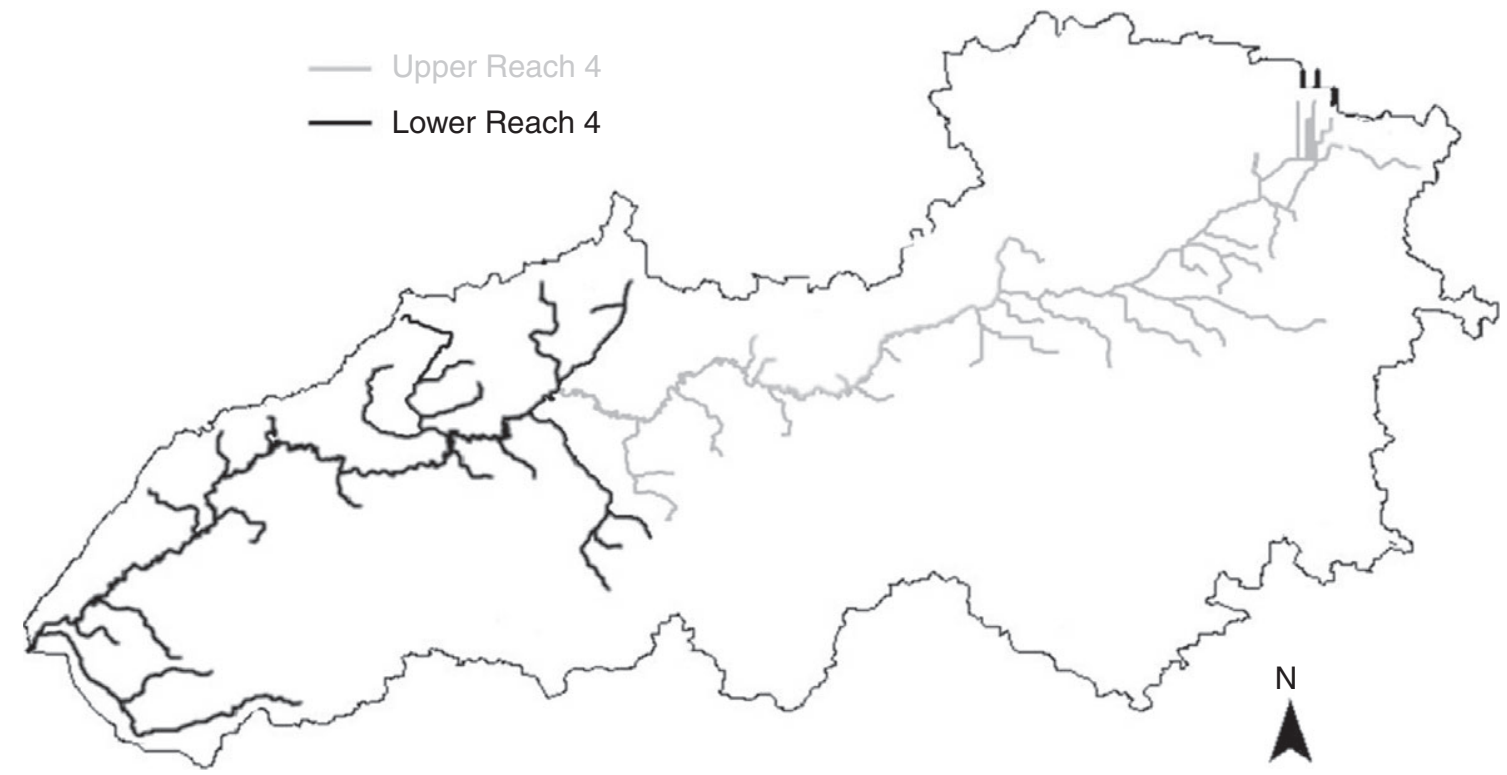

Fig. 6 Map of Reach 4 in the Paw River showing proposed segmentation to refine sea lamprey control. Proposed segmentation occurs on the Paw Paw River main stem $10.03 \mathrm{~km}$ from the mouth.

unionids are present in the Paw Paw River, our results show that at the site level, the presence of larvae and unionids overlaps minimally. Data on unionid distributions in systems that harbour sea lamprey are currently missing, and our study should be expanded to other systems. Refinement of sea lamprey control based on our results could be achieved by redefining the unit of treatment, namely subdividing current reach units, based on presence and relative densities of target and non-target species. In the Paw Paw River, based on ammocoete and unionid presence and distribution, Reach 4 - the largest reach in the system - can be segmented into two reaches (upper and lower Reach 4) $10.03 \mathrm{~km}$ from the mouth of the river (Fig. 6). Probability of age 1 and age $2+$ ammocoete presence within Reach 4 is variable: 0.67 and 0.78 in lower Reach 4, respectively, and 0.18 and 0.13 in upper Reach 4. Additionally, mean total ammocoete densities are higher in lower Reach 4 than in upper Reach 4-0.10 and 0.03 ammocoetes $\mathrm{m}^{-2}$, respectively. Thus, in upper Reach 4 - where unionids, and unionid habitat, are predominately found - the probability of ammocoete presence is low and densities are also low. Therefore, segmenting Reach 4 into two reaches - upper and lower - and not treating the upper segment where mussels are abundant is one possibility for refining treatment. Reach 4 has been treated frequently, potentially harming the unionids located in the area. Treating areas with higher probabilities of ammocoete presence and lower probabilities of unionid presence could result in reducing treatment costs and minimising threats to unionid conservation while still controlling the sea lamprey contribution to Lake Michigan. Ideally, the benefits of sea lamprey control should not come at the cost of impacting non-target species, particularly threatened taxa such as unionids. Results from this study indicated that sea lamprey control could be achieved with minimal impacts to the three more common unionids in the Paw Paw River. Similar analyses in other systems can demonstrate possibilities to minimise impacts to native biodiversity. Incorporating an additional task of recording the presence of unionid species during assessment surveys for sea lamprey larvae would further provide information to help understand overlap in distributions. This information, which should come at no additional cost, can be used for refining lampricide treatments with benefits for unionid conservation.

\section{Acknowledgments}

Thank you to Jamie Olson and Paul Gruber for their help in the field, and to Tom Neeson for sharing his calculations of sea lamprey habitat variables. Dr Paul Seelbach, Dr James Diana, Jeff Slade, Dr Mike Wiley and Dr Renee Sherman gave valuable insight and guidance.

\section{References}

Adlerstein S. \& Silverman E. (2008) Quantitative Tools to Predict Sea Lamprey Production Based on Habitat: Prioritizing Dam Removal and Control Decisions. Great Lakes Fishery Commission 2008 Project Completion Report, Ann Arbor, MI. 
Anonymous (2001) Larval Assessment Sampling Protocol Using the AbP-2 Backpack Electrofisher in Great Lakes Streams. Great Lakes Fisheries Commission Technical Report, Ann Arbor, MI.

Applegate V.C. (1950) Natural History of the Sea Lamprey (Petromyzon Marinus) in Michigan. U.S. Fish \& Wildlife Service, Special Scientific Report, Fisheries 55, Lansing, MI. Applegate V.C., Howell J.H. \& Moffett J.W. (1961) Use of 3-trifluoromethyl-4-nitrophenol as a selective sea lamprey larvicide. Great Lakes Fishery Commission, Technical Report No. 1, Ann Arbor, MI.

Badra P.J. (2010) Assessment of the Status and Distribution of Native Mussels (Unionidae) in Michigan, and Results of Unionid Surveys in the Eastern Upper Peninsula and HuronClinton Metroparks. Report to Michigan Department of Natural Resources and Environment, Water Bureau, Report No. MNFI 2010-11, Lansing, MI.

Badra P.J. \& Goforth R.R. (2003) Freshwater Mussel Surveys of Great Lakes Tributary Rivers in Michigan. Report No. MNFI 2003-15. Report to Michigan Department of Environmental Quality, Coastal Zone Management Unit, Lansing, MI.

Bence J.R. \& Smith K.D. (1999) An overview of recreational fisheries of the Great Lakes. In: Great Lakes Fisheries Policy and Management: a Binational Perspective (Ed. W.W. Taylor \& C.P. Ferreri), pp. 259-306. Michigan State University Press, East Lansing, MI.

Bills T.B., Rach J.J., Marking L.L. \& Howe G.E. (1992) Effects of the Lampricide Trifluoromethyl-4-Nitrophenol on the Pink Heelsplitter. U.S. Fish \& Wildlife Service, Resource Publication 183, Washington, DC.

Bogan A.E. (1993) Freshwater bivalve extinctions: search for a cause. American Zoologist, 33, 599-609.

Boogaard M.A., Bills T.D. \& Johnson D.A. (2003) Acute toxicity of TFM and a TFM/Niclosamide mixture to selected species of fish, including lake sturgeon (Acipenser fulvenscens) and mudpuppies (Necturus maculosus), in laboratory and field exposures. Journal of Great Lakes Research, 29 (Suppl. 1), 529-541.

Boogaard M.A., Kolar C.S. \& Waller D.L. (2004) Acute Toxicity of 3-Trifluoromethyl-4-Nitrophenol and a TFM -1\% Niclosamide Mixture to the Giant Floater (Pyganodon grandis), Fragile Papershell (Leptodea fragilis), and Pink Heelsplitter (Potamilus alatus) Unionid Mussels and Sea Lamprey (Petromyzon marinus) Larvae. Completion Report for Lake Champlain Fish \& Wildlife Management Cooperative, Vermont Department of Fish \& Wildlife, Essex Junction, Vermont.

Christie G.C. (2000) Protecting Mudpuppies, Protecting Stream Ecosystems. Forum for Stewardship and Sustained Benefits, Great Lakes Fishery Commission, Ann Arbor, MI.

Christie G.C. \& Goddard C.I. (2003) Sea Lamprey International Symposium - Advances in the integrated management of sea lamprey in the Great Lakes. Journal of Great Lakes Research, 29 (Suppl. 1), 1-14.

Christie G.C., Steeves T.B., Slade J.W., Cuddy D.W., Fodale M.F., Young R.J. et al. (2003) Selecting Great Lakes streams for lampricide treatment based on larval sea lamprey surveys. Journal of Great Lakes Research, 29 (Suppl. 1), 152160.

Dawson H.A. (2007) Recruitment Dynamics of Great Lakes sea Lamprey (Petromyzon marinus) Populations and Implications for Integrated Pest Management. PhD Dissertation. Michigan State University, East Lansing, MI.

Environmental Systems Research Institute (ESRI) (2009) ArcMap v. 9.3.1. Environmental Systems Research Institute, Redlands, CA.

Gilderhus P.A. (1979) Effects of Granular 2',5-Dichloro4'-Nitrosalicylanilide (Bayer 73) on Benthic Macroinvertebrates in a Lake Environment. Great Lakes Fishery Commission, Technical Report No. 34, Ann Arbor, MI.

Gilderhus P.A. \& Johnson B.G.H. (1980) Effects of sea lamprey (Petromyzon marinus) control in the Great Lakes on aquatic plants, invertebrates, and amphibians. Canadian Journal of Fisheries and Aquatic Sciences, 37, 1895-1905.

Hart R.A. (1995) Mussel (Bivalvia: Unionidae) Habitat Suitability Criteria for the Otter Tail River, Minnesota. MS Thesis. North Dakota State University, Fargo, ND.

Holland-Bartels L.E. (1990) Physical factors and their influences on the mussel fauna of a main channel border habitat of the upper Mississippi River. Journal of the North American Benthological Society, 9, 327-335.

Huehner M.K. (1987) Field and laboratory determination of substrate preferences of unionid mussels. Ohio Journal of Science, 87, 29-32.

Johnson D.A., Weisser J.W. \& Bills T.D. (1999) Sensitivity of Lake Sturgeon (Acipenser fulvescens) to the Lampricide 3-Trifluoromethyl-4-Nitrophenol (TFM) in the Field and Laboratory Exposures. Great Lakes Fishery Commission Technical Report 62, Ann Arbor, MI.

Klar G. \& Schleen L. (1999) Integrated Management of Sea Lampreys in the Great Lakes 1998. Annual Report to the Great Lakes Fishery Commission, Ann Arbor, MI.

Kondolf G.M. (1997) Application of the pebble count: notes on purpose, methods, and variants. Journal of the American Water Resources Association, 33, 79-87.

Master L.L., Stein B.A., Kutner L.S. \& Hammerson G.A. (2000) Vanishing assets: conservation status of U.S. species. In: Precious Heritage: the Status of Biodiversity in the United States (Eds Stein B.A., Kutner L.S. \& Adams J.S.), pp. 93118. Oxford University Press, New York.

McCullagh P. \& Nelder J.A. (1989) Generalized Linear Models. Chapman and Hall, London.

McLaughlin R.L., Marsden J.E. \& Hayes D.B. (2003) Achieving the benefits of sea lamprey control while minimizing effects on nontarget species: conceptual synthesis and proposed policy. Journal of Great Lakes Research, 29 (Suppl. 1), 755-765.

McRae S.E., Allan J.D. \& Burch J.B. (2004) Reach- and catchment-scale determinants of the distribution of freshwater mussels (Bivalvia: Unionidae) in south-eastern Michigan, U.S.A. Freshwater Biology, 49, 127-142. 
Ohio Environmental Protection Agency (Ohio EPA) (2006) Methods for Assessing Habitat in Flowing Waters: Using the Qualitative Habitat Evaluation Index (QHEI). Division of Surface Water, Ecological Assessment Section, Groveport, $\mathrm{OH}$.

Rankin E.T. (2006) Methods for Assessing Habitat in Flowing Waters: Using the Qualitative Habitat Evaluation Index. Midwest Biodiversity Institute for Ohio Environmental Protection Agency, Ecological Assessment Division, Groveport, $\mathrm{OH}$.

van der Schalie H. (1938) The naiad fauna of the Huron River in southeastern Michigan. Miscellaneous Publications of the University of Michigan Museum of Zoology, 40, 1-83.

Schleen L. \& Klar G. (2002) Integrated Management of Sea Lampreys in the Great Lakes 2001. Annual Report to the Great Lakes Fishery Commission, Ann Arbor, MI.

Seelbach P.W., Wiley M.J., Kotanchik J.C. \& Baker M.E. (1997) A Landscape-Based Ecological Classification System for River Valley Segments in Lower Michigan (MI - VSEC Version 1.0). Michigan Department of Natural Resources, Fisheries Research Report No. 2036, Lansing, MI.

Slade J.W., Adams J.V., Christie G.C., Cuddy D.W., Fodale M.F., Heinrich J.W. et al. (2003) Techniques and methods for estimating abundance of larval and metamorphosed sea lampreys in Great Lakes tributaries, 1995 to 2002. Journal of Great Lakes Research, 29 (Suppl. 1), 137-151.

Strayer D.L. (1981) Notes on the microhabitat of unionid mussels in some Michigan streams. American Midland Naturalist, 106, 411-415.

Strayer D.L. (1983) The effects of surface geology and stream size on freshwater mussel (Bivalvia: Unionidae) distribution in southeastern Michigan. Freshwater Biology, 13, 253-264.

Strayer D.L. (1993) Macrohabitats of freshwater mussels (Bivalvia:Unionacea) in streams of the Northern Atlantic Slope. Journal of the North American Benthological Society, 12, 236-246.

Strayer D.L. (2008) Freshwater Mussel Ecology: a Multifactor Approach to Distribution and Abundance. University of California Press, Berkeley, CA.

Strayer D.L. \& Ralley J. (1993) Microhabitat use by an assemblage of stream-dwelling unionaceans (Bivalvia), including two rare species of Alasmidonta. Journal of the North American Benthological Society, 12, 247-258.

Strayer D.L. \& Smith D.R. (2003) A Guide to Sampling Freshwater Mussel Populations. American Fisheries Society, Monograph 8, Bethesda, MD.

TIBCO Software Inc. (2007) S-PLUS v. 8.0.4, TIBCO Software Inc., Seattle, WA.

U.S. Fish \& Wildlife Service (1996) Nontarget Mortalities Observed During Lampricide Treatments in the State of Michigan, 1996. Michigan Department of Natural Resources, Surface Water Quality Division,, Lansing, MI.

Vaughn C.C. (1997) Regional patterns of mussel species distributions in North American rivers. Ecography, 20, 107115.

Vaughn C.C. \& Pyron M. (1995) Population ecology of the endangered Ouachita rock-pocketbook mussel, Arkansia wheeleri (Bivalvia: Unionidae), in the Kiamichi River, Oklahoma. American Malacological Bulletin, 11, 45-151.

Waller D.L., Bills T., Johnson D., Dolittle T., Luoma J. \& Hanson M. (1997) Determination of the Effects of the Lampricide TFM on Freshwater Mussels in the Bad River, Ashland County, Wisconsin. Report submitted to The Bad River Band of Lake Superior Tribe of Chippewa Indians, Odanah, WI.

Waller D.L., Rach J.J. \& Luoma J.A. (1998) Acute toxicity and accumulation of the pesticide 3-trifluoromethyl-4-nitrophenol (TFM) in freshwater mussels (Bivalvia: Unionidae). Ecotoxicology, 7, 113-121.

Williams J.D., Warren M.L., Cummings K.S., Harris J.L. \& Neves R.J. (1993) Conservation status of freshwater mussels of the United States and Canada. Fisheries, 18, 622.

Wolman M.G. (1954) A new method of sampling coarse riverbed. Transactions of the American Geophysical Union, 35, 951-956.

Young R. \& Klar G. (2003) Integrated Management of Sea Lampreys in the Great Lakes 2003. Annual Report to the Great Lakes Fishery Commission, Ann Arbor, MI.

(Manuscript accepted 22 February 2012) 